\title{
ČTRNÁCTÝ DODATEK ÚSTAVY USA A JEHO VÝKLAD Z POHLEDU HLAVNÍCH INTERPRETAČNÍCH METOD*
}

\author{
JAROSLAV ŽENÍŠEK
}

\begin{abstract}
The Fourteenth Amendment to the United States Constitution and Its Interpretation by Main Constitutional Interpretive Methods

The paper analyzes the Fourteenth Amendment to the United States Constitution, especially its first section and the clauses contained in it: the citizenship clause, the privileges or immunities clause, the due process clause and the equal protection clause and the historically variable interpretation of those by the Supreme Court, the decisions of which often accounted for fundamental changes in the perception of the provisions of the Fourteenth Amendment. Quite frequently, it was the Supreme Court that stood behind the significant social changes throughout history, whether in the area of racial segregation that still lasted for many years in the United States even after the end of the civil war, or later in the area of the right to privacy. The paper also deals with the approach of the dominant methods of interpretation to the Fourteenth Amendment, it compares the different approaches and the resulting interpretative conclusions. A special attention is dedicated to the contradictory interpretations of the originalist theory and the Living Constitution theory, the conflict between the advocates of these two lasting until today and still constituting an important part of the constitutional law debate in the United States.
\end{abstract}

Keywords: Constitution of the United States; Fourteenth Amendment; Supreme Court; interpretation

Klíčová slova: Ústava Spojených států; čtrnáctý dodatek; Nejvyšší soud USA; interpretace

DOI: $10.14712 / 23366478.2021 .1$

\section{1. ÚVOD}

Otázka výkladu ústavního textu je fenoménem, který provází ústavněprávní vývoj ve Spojených státech již od raných let existence americké státnosti, vzniklé osamostatněním třinácti kolonií na východním pobřeží severoamerického kontinentu od Britského impéria, které ani přes svou nespornou vojenskou převahu nedokázalo po osmi letech bojů zastavit separatistické snahy kolonií, vedené touhou po nezávislosti, jež vyústily roku 1789 v konečné ustanovení nového státního uspořádání, když 4. března onoho roku vešla v účinnost Ústava Spojených států amerických jako nejvyšší zákon, vymezující systém a fungování ustavené federativní ústavní republiky. Otcové

* Tento př́íspěvek vznikl na základě plné finanční podpory a je výstupem projektu SVV č. 260358 řešeného na Právnické fakultě Univerzity Karlovy s názvem Kritická analýza pramenů práva se zřetelem na problémy jejich interpretace a retroaktivitu. 
zakladatelé Spojených států vtiskli Ústavě její charakteristickou podobu, ovlivněnou prrirozenoprávní naukou, evropským osvícenstvím a liberalismem 18. století, postavenou na principech striktní dělby moci, federalismu, limitované působnosti státu a široké míry občanských svobod.

Jedním z typických rysů amerického systému je specifická role soudů, coby institucí nejen rozhodujících v otázkách de lege lata, tedy „co je po právu“, nýbrž také právo dotvářejících. Jsou to právě soudy, jež hrály v historii Spojených států již od počátku mnohdy klíčovou roli při interpretaci textu Ústavy a jejichž rozhodnutí ovlivnila nikoli pouze obecné chápání konkrétních ustanovení Ústavy, ale měla přímý a nezř́́dka rozhodující vliv na společensko-politický vývoj Spojených států. V této oblasti vyniká činnost Nejvyššího soudu USA, stojícího na samotném vrcholu federální soudní soustavy, o níž jsou vedeny trvalé spory, a to zdaleka nejen v právních kruzích. Význam rozhodnutí Nejvyššího soudu spočívá jak v jejich precedenčním charakteru, tak především v pravomoci soudního přezkumu (judicial review), formálně ustavené legendárním předsedou Nejvyššího soudu Johnem Marshallem roku 1803 v dnes již proslulé kauze Marbury v. Madison, ${ }^{1}$ díky níž je Nejvyšší soud schopen podrobit akty legislativy vlastnímu přezkumu a v př́ípadě jejich rozporu s Ústavou je prohlásit za neplatné.

Problematika výkladu Ústavy je tématem komplexním a nesnadným. Úloha vykladače ústavního textu je ztížena dvěma signifikantními faktory - prvním je faktor času, druhým poté faktor obecnosti. Ústava Spojených států je nejstarší psanou ústavou na světě, jde o ústavu rigidní - proces přijímání nových dodatků k Ústavě vyžaduje k jejich schválení dvoutř̌etinovou většinu obou komor Kongresu (Sněmovny reprezentantů a Senátu) a dále ratifikaci alespoň třemi čtvrtinami všech států Unie. ${ }^{2}$ Od roku 1790 , kdy došlo $\mathrm{k}$ ratifikaci Ústavy státem Rhode Island, jako posledním z původních třinácti kolonií, bylo k dnešnímu dni přijato celkem 27 dodatků, poslední, dodatek sedmadvacátý, se dočkal ratifikace roku 1992. Zatímco potenciální nejasnosti panující u dodatků Ústavy, príjatých v průběhu století dvacátého, mohou být díky relativní časové blízkosti úspěšně rozptýleny, text samotné Ústavy i jejích prvních deseti dodatků pochází z konce osmnáctého století, vlivem čehož se před jejich vykladačem objevuje poměrně obtížná překážka. Obdobně je tomu u dodatků jedenáctého až patnáctého, jež byly k Ústavě prripojeny v druhé polovině století devatenáctého.

Neméně složitou překážkou je poté vykladači obecná povaha mnohých ústavních pasáží a klauzulí. Generalita termínů, jako jsou kupř́íladu „stejná ochrana zákona“ či „svobody nebo výsady“, obsažené ve čtrnáctém dodatku, zapřičiňuje, že ti, kdo je interpretují, docházejí k odlišným závěrům, z nichž následně plynou spory o to, jaký př́stup je ten, který nejlépe povede ke správnému závěru. Díky tomu zaznamenáváme v průběhu času vznik různých interpretačních teorií, vycházejících z odlišných premis a užívajících odlišných metod $\mathrm{k}$ objasnění smyslu ústavních ustanovení za účelem jejich aplikace. Debaty mezi zastánci té či oné výkladové teorie reflektují např́íc dějinami pochopitelně také rozsudky Nejvyššího soudu USA, který v závislosti na převaze jednotlivých právních filozofí́ jeho členů dospíval a stále dospívá k početným

SELTENREICH, R. - KUKLÍK, J. Dějiny angloamerického práva. 2. vyd. Praha: Leges, 2011, s. 535-539.

Ústava Spojených států amerických, čl. 5. 
rozhodnutím, budícím kontroverze a velmi živé diskuse mezi právníky, ale i širokou veřejností.

\section{INTERPRETACE ÚSTAVNÍHO TEXTU A VÝKLADOVÉ TEORIE}

Jaký je účel Ústavy? Pokud se pokoušíme o výklad ústavního textu, tuto otázku nelze opomenout. Právě u ní totiž začíná cesta každého vykladače, snažícího se nalézt $\mathrm{v}$ Ústavě řešení konkrétního právního problému. Ptáme-li se, zda je určité právo v Ústavě obsaženo, či zda Ústava něco dovoluje, nebo naopak zapovídá, vycházíme již ze situace, že víme, jaká je role Ústavy, proč vůbec byla přijata a proč má svůj význam pro společnost i stát.

Ústavu Spojených států můžeme rozdělit na dvě části - část první, to jest preambuli a vlastní články I-VII, a část druhou, kterou jsou její dodatky, schválené a ratifikované v dobách následujících po ratifikaci samotných článků Ústavy. Smyslem části první je vymezení institucionální struktury a ustavení jednotlivých složek státní moci - moci zákonodárné, výkonné a soudní - a vymezení jejich pravomocí a procesů, v rámci nichž budou vykonávat svou činnost, jak jim ji Ústava předepisuje. Smysl části druhé, tedy ústavních dodatků, se liší v závislosti na jejich povaze. Mezi dodatky lze rozlišit v zásadě dva typy - i) dodatky, doplňující či pozměňující ustanovení článků, jako je např́íklad dodatek dvaadvacátý, upravující funkční období prezidenta, a ii) dodatky, vztahující se k občanským právům a svobodám, jakými jsou zejména dodatky I-X, známé jako Listina práv (Bill of Rights). Účelem a smyslem Ústavy je tedy nejen vymezení státní struktury, ale také ochrana těch práv a svobod, které jsou dle jejích tvůrců natolik významné a esenciální, že nelze dopustit, aby byla, byt' demokratickým rozhodnutím většiny, menšině upírána. Jeden z „otců Ústavy“, slavný James Madison, ve Federalistovi č. 10, kde detailně rozebírá hrozbu útlaku menšiny ze strany většiny, plynoucí z tzv. „stranictví” - společného cíle, zájmu, jaký většina sleduje, jenž je však v rozporu s právy menšin -, píše:

„Odevšad slyšíme stižnosti našich nejváženějšich a nejctihodnějšich občanů, zastánců jak veřejné i osobni víry, tak veřejné i osobni svobody, že naše vlády jsou príliš nestálé, že ve sporech různých stran je přehliženo veřejné blaho a rozhodnutí jsou často přijímána nikoli na základě zásad spravedlnosti a s ohledem na práva menšiny, nýbrž podle větši sily zaujaté a zpupné většiny. "3

Ve Federalistovi č. 51 Madison navazuje na myšlenku ochrany menšiny, když hovoří o potřebě ,, vưle, nezávislé na většině, jinými slovy vůle nezávislé na samé společnosti “, 4 jež bude př́tomna ve státu - půjde tedy o existenci kontroly, zábrany, jež zastaví př́ipadné snahy většiny o prosazení vůle, která bude svou povahou utlačující vůči menšině. Touto zábranou má být právě Ústava, jež v sobě uchovává přirozená práva a brání jejich odnětí jak ze strany prosté většiny společnosti, tak státu samého.

3 HAMILTON, A. - MADISON, J. - JAY, J. The Federalist Papers. Londýn: Penguin Books Ltd., 1987, s. 123.

4 Tamtéž, s. 322. 
Avšak i pokud je vykladači známa role Ústavy a její funkce, stále před ním stojí úkol zjistit, kde staví její text onu pomyslnou hranici, již nelze překročit a u níž končí pravomoc většiny přijímat rozhodnutí, dopadající na menšinu, nebot' text Ústavy nehovoří vždy natolik jednoznačně, aby o způsobu jeho aplikace na projednávanou otázku nemohlo býti pochyb. Vyvstává zde tedy potřeba rozhodnutí, které soudce a svého času také nominant prezidenta Reagana na Nejvyšší soud Robert Bork označuje jako „madisonské dilema“", 5 spočívající v existenci dvou vzájemně se střetávajících zájmů majority a minority. Zájmem majority je vládnout dle své vůle, zájmem minority je udržet si sféru práv a svobod, v níž majorita nebude moci působit. Jak nalézt hranici mezi nimi je podstatou „madisonského dilematu“ a je také samým jádrem sporu mezi jednotlivými výkladovými teoriemi.

\subsection{ORIGINALISMUS}

\subsubsection{ORIGINAL MEANING}

Originalistická metoda výkladu je velmi blízká metodě textualistické, orientované na psaný text. Stejně jako textualismus i originalismus klade důraz na př́sné držení se textu, nejpodstatnějším rysem originalistické teorie je však snaha o výklad, který bude v souladu s „původním významem“ (original meaning) či také „původním chápáním“ (original understanding). Ústava a její dodatky mají dle této koncepce být vykládány tak, jak byly chápány v době jejich přijetí, a také v souladu s významem, jaký jim přisuzovali ti, kdo je ratifikovali. ${ }^{6}$ Originalistické pojetí bývá - byt' ne zcela výlučně - spojováno s konzervativněji a tradicionalisticky zaměřenými soudci. Bývalý soudce Nejvyššího soudu Antonin Scalia pregnantně shrnul originalistickou teorii ve svém projevu v Atlantě z roku 2014: „Ústava není živým organismem. Je to právní dokument, který ríká to, co říká, a neříká to, co neříká. "7 Originalismus je metodou, kladoucí důraz na limitovanou roli soudce při výkladu Ústavy a stojí v tvrdé opozici ke koncepci soudcovského dotváření práva skrze soudní přezkum, kterou vidí jako nepř́ípustné překročení pravomocí, svěřených soudům Ústavou, vedoucí v důsledku k narušení principu dělby moci a povyšující soudce do role nevolených, nikým nekontrolovaných zákonodárců, schopných nahradit vůli pravých demokraticky zvolených zástupců lidu. Kořeny originalismu nalézáme již u samotných Otců zakladatelů. Alexander Hamilton v textu Federalisty č. 78 zdůrazňuje, co má být úkolem soudce: aplikovat úsudek, nikoli vůli. ${ }^{8}$ Stejně tak James Madison v dopise z 25. června 1824, adresovaném Henrymu Lee IV., vyjadřuje podporu myšlence výkladu Ústavy, korespondujícího

5 BORK, R. H. The Tempting of America: the Political Seduction of the Law. New York: Touchstone, 1991, s. 139.

6 Tamtéž, s. 144.

7 DUNCAN, R. F. Justice Scalia and the Rule of Law: Originalism vs. the Living Constitution. Regent University Law Review [online]. 2016-2017, Vol. 29, No. 1, s. 12 [cit. 2020-09-11]. Dostupné na: https:// digitalcommons.unl.edu/cgi/viewcontent.cgi?article $=1200 \&$ context $=$ lawfacpub.

8 HAMILTON - MADISON - JAY, c. d., s. 440. 
s významem, jaký v ní spatřovali ti, kdo Ústavu ratifikovali. ${ }^{9}$ Řešení madisonského dilematu, jak jej prosazují vykladači-originalisté, spočívá v odvození a definování neutrálního principu, vykazujícího odpovídající míru obecnosti. Tento princip je následně aplikován, rovněž za dodržení př́sné neutrality. Tam, kde poté Ústava nehovoří a není možné původní princip nalézt, nemají dle originalistického pojetí hovořit ani soudci, nebot' by v takovém prípadě dali průchod vlastní vůli namísto pouhého určení původního významu a jeho aplikace na projednávaný prípad. Někteří známí originalisté vidí metodu originalismu jako jedinou cestu, vedoucí k jak správnému výkladu, tak k dodržení principu oddělených složek moci, ${ }^{10}$ jiní zdůrazňují př́nos originalismu jako metody, zachovávající „dobrou Ústavu“, která prošla procesem schválení supervětšinou (supermajority), z čehož lze usuzovat její kvalitu. ${ }^{11}$ Naproti tomu ze strany ústavních právníků a právních teoretiků, oponujících tezi původního významu, jsou originalistické teorii vytýkány její složitost, ${ }^{12}$ projevující se při pokusech o nalezení původního významu, nemožnost zachování neutrality při definování principů ${ }^{13}$ a také neschopnost adaptace na společenské změny a upřednostňování minulého nad současným, uvrhující moderní společnost do zajetí tradic dávno zesnulých.

\subsubsection{ORIGINAL INTENT}

Teorie „původního záměru“ (original intent) bývá zmiňována vedle metody původního významu jako druhý ze dvou druhů originalismu. Od originalismu původního významu se však tato v podstatných znacích odlišuje. Zatímco originalisté, přiklánějící se ke koncepci původního významu, odkazují na původní chápání ústavního textu, intencionalisté pátrají po původním záměru jeho tvůrců. ${ }^{14}$ To, na čem dle intencionalistické metody záleží, tedy není výsledný psaný text, nýbrž záměr, s jakým byl tento text napsán. Rozhodující je tedy subjektivní vůle tvůrců, byt’ vykládaný text může hovořit zcela jinak. Tato metoda je však originalisty, klonícími se k metodě původního významu, odmítána ${ }^{15}$ a obecně nepatř́i k populárním způsobům výkladu.

\subsection{TEXTUALISMUS}

Jak bylo zmíněno výše, textualistická metoda soustředí svůj zájem na psaný text a jeho znění. Metodika textualismu spočívá ve snaze zjistit „prostý význam“ vykládaného textu, tedy zjistit, jak by dané ustanovení chápala „normální, anglicky

9 National Archives [online]. [cit. 2020-09-11]. Dostupné na: https://founders.archives.gov/documents /Madison/04-03-02-0333.

10 BORK, c. d., s. 143.

11 MCGINNIS, J. O. - RAPPAPORT, M. B. Originalism and the Good Constitution. Cambridge: Harvard University Press, 2013, s. 82.

12 BREST, P. The Misconceived Quest for the Original Understanding. Boston University Law Review [online]. 1980, Vol. 60, s. 213 [cit. 2020-09-11]. Dostupné na: https://heinonline.org/HOL/Page?collection $=$ journals\&handle $=$ hein.journals $/$ bulr60\&id $=1 \&$ men_tab $=$ srchresults.

13 SELTENREICH - KUKLÍK, c. d., s. 603.

14 SCALIA, A. A Matter of Interpretation: Federal Courts and the Law. Princeton: Princeton University Press, 1997, s. 38.

15 BORK, c. d., s. 144. 
hovořici osoba $v$ době jeho príieti “ " ${ }^{16} \mathrm{~V}$ odpovědi na otázku, co přesně textualista hledá v textu, který před ním leží, odpovídá Antonin Scalia - zřejmě největší ikona textualismu posledních dekád - tak, že textualista nepátrá po subjektivním legislativním záměru, pátrá po záměru, jaký by si z textu odvodila „rozumná osoba“ (reasonable person), jíž je adresován. ${ }^{17}$ Zde nalézáme viditelnou shodu s postupem, uplatňovaným teorií originalistickou. Citujíc již legendárního někdejšího soudce Nejvyššího soudu Olivera Wendella Holmese jr., Scalia poté dodává ,, nezajímá mne, jaký byl zámèr, zajímá mne pouze to, co užitá slova znamenaji “ ${ }^{18}$ Sám Scalia rozlišuje mezi interpretací zákonů, u nichž užívanou metodu označuje jako textualistickou, ${ }^{19}$ a interpretací ústavního textu, u kterého pro změnu hovoří o metodě originalistické, která ovšem vychází ze základních textualistických principů a slouží tedy jako určitý specifický typ textualismu pro ústavní text. ${ }^{20}$

\subsection{LITERALISMUS}

Z textualistického pojetí vychází následně teorie ,striktního konstrukcionismu“ (strict constructionism), či také literalismu, pod niž jsou někdy jak textualismus, tak originalismus nesprávně zařazovány. Striktní konstrukcionismus je svou povahou extrémní verzí textualismu, ale na rozdíl od něho tento odmítá při výkladu jakýkoli faktor vyjma doslovného znění textu. Soudce Nejvyššího soudu Hugo Black v př́ípadu Mishkin v. New York z roku 1996, týkajícím se vlastnictví materiálů obscénní povahy a jeho (ne)ochrany prvním dodatkem Ústavy, poskytl ve svém disentu přesný vhled do filozofie striktního konstrukcionismu, kde rezolutně odmítl možnost federální vlády jakkoli regulovat jakýkoli projev, nebot' první dodatek dle Blacka explicitně ř́ká, že „Kongres nesmí vydat žádný zákon, omezujicí svobodu slova“, a „žádný" znamená skutečně ,,vi̊bec žádný “. ${ }^{21}$ Blackovo absolutistické pojetí textualismu je nicméně kritizováno i mezi ostatními textualisty, dle nichž aplikování prostého textu za absence zvážení jazykového a společenského kontextu při jeho čtení znamená velké riziko vzniku závěrů, jež budou charakteru až absurdního. ${ }^{22}$

\subsection{TEORIE „ŽIVÉ ÚSTAVY“}

Jak lze odtušit již ze samotného termínu „živá Ústava“, metoda interpretace Ústavy coby dokumentu, jehož význam je závislý na běhu času a době, v níž je vykládán, stojí v prímém protikladu $\mathrm{k}$ teorii originalistické. Teoretici, hlásící se $\mathrm{k}$ této koncepci, staví svou argumentaci na potřebě doplňování a dodatečného „vylepšení“ textu Ústavy, který dle nich vlivem doby, v níž byl prrijat, a jejího společenského kontextu, obsahuje mezery, kvůli nimž Ústava poskytuje nedostatečnou ochranu některých práv, objevených až mnoho let po její ratifikaci díky postupujícímu dějinnému

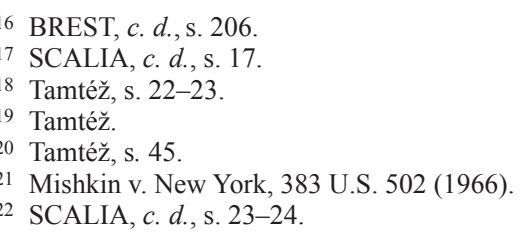


vývoji a s ním souvisejícími novými společensko-politickými standardy, na které text z konce 18. století ve své původní podobě nedokáže adekvátně reagovat. Proto zastánci konceptu Ústavy coby „žijícího“ dokumentu (Living Constitution) podporují širší pole působnosti pro soudce při interpretaci, aby svou činností dané mezery vyplnili prostřednictvím extenzivnějšího výkladu. Soudce Nejvyššího soudu Thurgood Marshall, jeden z předních stoupenců teorie živé Ústavy, ve svém projevu k dvoustému výročí vzniku Ústavy Spojených států kriticky hodnotí Ústavu jako dokument, jehož význam není pevně dán, a státní uspořádání v podobě, v jaké bylo navrženo Otci zakladateli, coby „, defektní od samého počátku “.23 Marshallova razantní kritika pramení z historicky známých nedostatků, prítomných i v americké společnosti 18. a 19. století a reflektovaných i v samotné Ústavě, ${ }^{24}$ jakými byly otroctví a obecně inferiorní postavení afroamerické populace, stejně jako postavení žen, disponujících plošně volebním právem až od přijetí devatenáctého dodatku na počátku dvacátého století. Tyto nepochybné historické křivdy pro Marshalla, jakož i ostatní teoretiky metody živé Ústavy, znamenají potřebu číst Ústavu jako dokument, jehož význam je proměnlivý a dynamicky se rozvíjející s rozvojem obecného celospolečenského chápání práv a svobod. ${ }^{25}$ Role soudců jako arbitrů, dotvářejících svými rozhodnutími právo na užití soudního přezkoumávání, jež jim přisuzuje teorie živé Ústavy, je nejčastějším terčem kritiky ze strany textualistů a originalistů, považujících za jediný legitimní postup při změnách ústavního textu proces upravený pátým článkem Ústavy a argumentujících pokřivením systému dělby mocí vlivem tzv. „soudcovského aktivismu“, ${ }^{26}$ vedoucího v konečném důsledku k faktickému „soudcokratickému“" zř́zení.

Originalismus na straně jedné, vycházející z formalistického pojetí práva, a teorie živé Ústavy, představující větší právní pragmatismus, na straně druhé, jsou dnes dvěma nejvýznamnějšími výkladovými metodami, jejichž dlouhotrvající střet je fenoménem, symptomatickým pro problematiku interpretace Ústavy jako takové. Konfrontaci těchto dvou př́istupů můžeme sledovat u těch nejdůležitějších rozhodnutí amerického Nejvyššího soudu, týkajících se rozsahu občanských práv a svobod a př́pustné míry státní ingerence, pokrývajících jednotlivé ústavní dodatky. Ani čtrnáctý dodatek není v tomto směru výjimkou.

Je ovšem nutné zmínit, že interpretační př́stupy, nastíněné v textu výše, jsou sice metodami dominantními, avšak nejsou metodami jedinými, za zmínku dozajista stojí např́ílad také metoda pragmatická, orientovaná na zkušenost a konsekvence, ${ }^{27}$ nahlížející na jednotlivé kauzy prizmatem následků, jaké by rozhodnutí soudního orgánu přineslo, a zvažující při výkladu žádoucí společenské dopady a specifická pozitiva a negativa řešené otázky, ${ }^{28}$ namísto abstraktnějš́ího, teoretičtějšího př́stupu, jaký volí

23 The Bicentennial Speech. In: Thurgood Marshall [online]. 2019 [cit. 2020-09-11]. Dostupné na: http:// thurgoodmarshall.com/the-bicentennial-speech/.

24 Ústava Spojených států amerických, čl. 1, odd. 2.

25 The Bicentennial Speech. In: Thurgood Marshall [online]. 2019 [cit. 2020-09-11]. Dostupné na: http:// thurgoodmarshall.com/the-bicentennial-speech/.

26 BORK, c. d., s. 17.

27 FARBER, D. A. Legal Pragmatism and the Constitution. Minnesota Law Review [online]. 1988, Vol. 72, s. 1341 [cit. 2020-09-11]. Dostupné na: https://scholarship.law.umn.edu/cgi/viewcontent.cgi?article $=2083 \&$ context $=\mathrm{mlr}$.

28 Tamtéž, s. 1342-1343. 
kupříkladu metoda originalistická. Každá z výkladových teorí je však subjektivního charakteru, kdy ani jedna z metod není metodou výlučnou a jejich ne/užití závisí na konkrétním složení soudního orgánu. Proto také lze v různých historických obdobích pozorovat i různé změny a obraty v právním prístupu na Nejvyšším soudu, viz kupř́íkladu kontrast mezi Nejvyšším soudem Warrenovým v padesátých a šedesátých letech minulého století a soudem Rehnquistovým v letech osmdesátých, devadesátých a na počátku století dvacátého prvého.

\section{3. ČTRNÁCTÝ DODATEK ÚSTAVY SPOJENÝCH STÁTŮ}

Čtrnáctý dodatek k Ústavě USA patří nepochybně k nejvýznamnějším změnám, jaké původní Ústava doznala. Pět oddílů, tvořících tento dodatek, obsahuje klauzule, které v době přijetí představovaly revoluční změny pro americkou společnost, zotavující se z občanské války a stojící jak před výzvou znovusjednocení federace, tak potřebou odstranění přetrvávajících nerovností v občanských a politických právech. Čtyři klauzule, zahrnuté do čtrnáctého dodatku - o občanství, o svobodách nebo výsadách, o řádném soudním procesu a o stejné ochraně zákona - fungují dodnes jako základ pro rozhodování Nejvyššího soudu v kauzách, dotýkajících se rozsahu práv a svobod a ochrany před diskriminačním zacházením. Rozsudky v př́padech, týkajících se čtrnáctého dodatku, jakými byly Plessy v. Ferguson, Slaughter-House Cases, Brown v. Board of Education, Griswold v. Connecticut či Roe v. Wade, představují milníky ve vývoji interpretace ústavního textu i amerického ústavního práva jako celku.

\subsection{HISTORICKÉ POZADÍ}

Po vítězství severních států v občanské válce, trvající v letech 1861-1865, vyvstala potřeba nalézt způsob, jak začlenit poražené jižanské státy Konfederace zpět do Unie. Toto byl nicméně značně komplikovaný úkol - vítězný Sever byl po válce politicky rozdělen na ty, kteří prosazovali umírněnost a shovívavost vůči členům bývalé Konfederace, mezi něž patřil i prezident Lincoln, a radikální republikány, mezi kterými vynikali zejména senátor Charles Sumner a kongresman Thaddeus Stevens, požadující větší nekompromisnost a potrestání odtržených států. Rozpor mezi oběma tábory znamenal faktickou nemožnost shody na jednotném plánu, na jehož základě by proběhla obnova Unie v předválečné podobě. Lincolnova snaha o smírné řešení, vedená v duchu zásady „,bez zášti vi̊či komukoli a se shovívavostí vi̊či všem “",29 projevená v podobě návrhu tzv. desetiprocentního plánu, ${ }^{30}$ narazila na tvrdou opozici radikálů v Kongresu, usilujících o přijetí vlastní koncepce rekonstrukce, tzv. Wade-Davisova zákona, ${ }^{31}$ pro změnu vetovaného prezidentem. Prezident Andrew Johnson, jenž se ujal

29 Great inaugural addresses: Abraham Lincoln's two speeches. In: National Constitution Center [online]. 18. 1. 2017 [cit. 2020-09-11]. Dostupné na: https://constitutioncenter.org/blog/great-inaugural-speeches -abraham-lincoln.

30 SELTENREICH - KUKLÍK, c. d., s. 400.

31 Tamtéž. 
úřadu po Lincolnově zavraždění, navázal na Lincolnovu umírněnou politiku a prosazoval co nejrychlejší návrat jižních států do Unie. Rekonstrukční proces, během něhož docházelo k postupnému znovupřijetí odtržených států, vyústil nakonec v rozdělení Jihu na vojenské distrikty pod správou Severu. Toto uspořádání vydrželo až do roku 1877, kdy po dohodnutém kompromisu ${ }^{32}$ došlo k odchodu severních vojenských jednotek, znamenajícímu definitivní završení éry Rekonstrukce USA. ${ }^{33}$

Obnovení Unie však nebylo jediným úkolem, s nímž bylo třeba se po skončení války vypořádat. Stále nedořešenou zůstávala problematika postavení afroamerické části populace, které navzdory zrušení otroctví na celém území Spojených států třináctým dodatkem Ústavy z roku 1865, navazujícím na prezidentské prohlášení o osvobození otroků na území Konfederace z roku 1863, stále mělo daleko do skutečného zrovnoprávnění. Reakcí na tuto skutečnost bylo přijetí Zákona o občanských právech (Civil Rights Act) roku 1866, schválenému i přes veto prezidenta Johnsona, a dvou dalších ústavních dodatků - čtrnáctého (1868) a patnáctého, zakazujícího upírání volebního práva na základě rasy, barvy pleti nebo předchozího otroctví, (1870). Společně s třináctým dodatkem tvoří tyto sérii tzv. Rekonstrukčních dodatků, pokoušejících se zakotvit na federální ústavní úrovni rovné postavení a přístup k právům bez ohledu na barvu pleti, tedy aspekt, jenž doposud v Ústavě nebyl př́itomen, čehož jednotlivé jižanské státy v minulosti využívaly k přijetí zákonů, omezujících selektivně část obyvatelstva $\mathrm{z}$ čistě rasových důvodů. ${ }^{34}$

Ani připojení tří nových dodatků k Ústavě však neznamenalo naprostý konec rasové segregace a diskriminace. Státy bývalé Konfederace, navzdory vědomí, že spor o otroctví je definitivně ztracený, nehodlaly akceptovat úplný přechod ke zrovnoprávnění a hledaly tak způsob, jak novou právní úpravu obejít. Výsledkem bylo přijímání tzv. „Černých zákoníkư“ (Black Codes), ${ }^{35}$ na něž později navázaly nechvalně proslulé „zákony Jima Crowa“. ${ }^{36}$ Cílem těchto lokálních právních úprav bylo faktické zachování segregace, projevující se nejvýrazněji na pokračujícím vyřazování Afroameričanů z účasti na volebním procesu. Tento stav, posvěcený i některými rozsudky Nejvyššího soudu, přetrvával v př́štích dekádách až do poloviny dvacátého století.

Roku 1964 byl poté Kongresem schválen další Zákon o občanských právech, který na rozdíl od de facto neúčinného stejnojmenného předpisu z roku 1866 již znamenal značný průlom v rasové desegregaci. Význam čtrnáctého dodatku zde však na rozdíl od dodatku patnáctého nekončil. Následující léta s sebou přinesla nová politická témata,jakými byly ochrana soukromí, potraty či postavení sexuálních menšin, která se promítla i do rozhodování Nejvyššího soudu, odkazujícího v nich právě na ustanovení čtrnáctého dodatku, který se zejména díky v něm obsažené klauzuli substantive due process stal prostředkem k vynětí dalších práv z rozhodování společenské většiny, kterým setrvává i nadále.

\footnotetext{
KUST, J. Nejvyšší soud USA. Praha: Ústav práva a právní vědy, o. p. s., 2013, s. 91.

Tamtéž.

Tamtéž, s. 90.

SELTENREICH - KUKLÍK, c. d., s. 402.

KUST, c. d., s. 90-91.
} 


\subsection{INTERPRETACE ČTRNÁCTÉHO DODATKU}

Zatímco formulace oddílů 2-4 čtrnáctého dodatku nezavdává velký prostor k pochybám ohledně jejich významu a výkladu, pravý opak platí pro oddíl první, ${ }^{37}$ díky němuž je význam celého dodatku povýšen z čistě institucionální úpravy, reagující na státoprávní potřeby rekonstrukčního procesu, na naprosto klíčové ústavní ustanovení pro ochranu práv a výsad, pojících se s občanstvím USA i jednotlivých států, a díky kterému je text, jenž by jinak s postupem času nepochybně ztrácel na relevanci a proměnil se spíše jen v téma pro právní historiky, jádrem disputací i více než sto padesát let po jeho přijetí. Výše jmenované čtyři klauzule prvního oddílu se ukázaly jako nadčasové, ovšem zda tomu tak skutečně mělo (a má dále) být, je otázka, jež je předmětem následujících odstavců.

\subsubsection{OBČANSTVÍ A PRIVILEGES OR IMMUNITIES}

První dvě klauzule prvého oddílu - klauzule o občanství a klauzule o svobodách nebo výsadách - jsou vzájemně bezprostředně navazující a dohromady vytvářejí jak rámec pro určení, zda určité osobě náleží občanství a k němu přináležející „svobody nebo výsady“ (privileges or immunities), díky čemuž došlo ke zvrácení rozsudku, vyneseného v předválečném př́padu Dreda Scotta, ${ }^{38}$ tak také jakých ,svobod nebo výsad“ se podmínka o jejich neomezování ze strany jednotlivých států týká. Jak totiž můžeme vyčíst ze samotného textu čtrnáctého dodatku, občanství ve Spojených státech je dvojíkaždý, koho lze zahrnout pod uvedenou definici - tedy je narozený nebo naturalizovaný v USA a spadá pod jejich jurisdikci - je nejen občanem USA jako celku, ale také konkrétního státu, jehož je obyvatelem. Rozdělení, vyplývající z federálního uspořádání, je zásadní, nebot' obě občanství nejsou svou povahou totožná a každé s sebou nese odlišné skutečnosti, včetně odlišných ,svobod nebo výsad“.

Tato disparita $\mathrm{v}$ minulosti vedla $\mathrm{k}$ tomu, že zatímco na federální úrovni byla zejména díky Bill of Rights jistá práva chráněna před vládními zásahy, na úrovni státní tomu tak nebylo, čehož bylo státními legislativami hojně využíváno, jak lze vidět na příkladech zmíněných „Černých zákoníkư“. Vyvstala proto otázka, zda je možné práva, garantovaná Bill of Rights, aplikovat i na činnost státních legislativ, a nikoli pouze coby pojistku proti vládě a legislativě federální. Ta byla centrálním problémem, který řešil Nejvyšší soud v kauze tzv. ,jatečních prrípadư“ (Slaughter-House Cases) z roku 1873. Ve městě New Orleans ve státě Louisiana vlivem znečišt'ování okolního prostředí odpadem z jatek, které vedlo k propuknutí epidemií, přijala státní legislativa opatření, kterým došlo ke vzniku centralizovaného jatečního monopolu na úkor všech ostatních soukromých jatek, která měla být uzavřena. Místní řezníci proto podali několik žalob k Nejvyššímu soudu s cílem zastavit proces monopolizace jatečního odvětví. Nejvyšší soud však ná-

37 „V̌̌echny osoby narozené nebo naturalizované ve Spojených státech a podřizené jejich jurisdikci jsou občany Spojených států a státu, jehož jsou obyvateli. Žádný stát nemá právo vydat nebo provádět zákon, který by omezoval svobody nebo výsady občanů Spojených států; žádný stát nemá právo zbavit jakoukoli osobu života, osobni svobody nebo majetku bez řádného soudniho procesu; nemá také právo zbavit jakoukoli osobu, podléhající jeho pravomoci, stejné ochrany zákona. “

38 Dred Scott v. Sandford, 60 U.S. 393 (1857). 
roky řezníků zamítl s tím, že klauzule o „svobodách nebo výsadách“ chrání pouze proti federálním zásahům, a nikoli také proti zásahům jednotlivých států, protože žádný stát sice nemůže vydat zákon, omezující svobody nebo výsady občanů Spojených států, to ale neznamená, že nemůže omezit svobody a výsady, vyplývající z občanství státního, které nejsou pod ochranou čtrnáctého dodatku a jeho klauzule o „svobodách nebo výsadách". Argumentace soudce Samuela Millera ve většinovém stanovisku byla postavena na tvrzení, že kdyby smyslem klauzule o svobodách nebo výsadách bylo chránit občany proti jejich vlastnímu státu, bylo by toto $\mathrm{v}$ textu jasně stanoveno, namísto toho však text hovoří pouze o občanech „Spojených státư“, přičemž ale v př́edcházející klauzuli o občanství mezi těmito dvěma jednoznačně rozlišuje. ${ }^{39}$

Rozhodnutí v kauze jatečních př́ípadů tak potvrdilo dosavadní praxi neaplikovatelnosti ${ }^{40}$ Bill of Rights na jednotlivé státy USA. Plyne $\mathrm{z}$ něho však ještě jeden důležitý závěr: totiž že pojem „svobod nebo výsad“ nezahrnuje práva nevyčtená výslovně v ústavním textu, ale „náležející lidu“, o nichž hovoří devátý dodatek k Ústavě. Pojem „svobody nebo výsady“, s nímž pracuje čtrnáctý dodatek, nachází inspiraci u ustanovení o „,svobodách $a$ výsadách“, obsaženém ve čtvrtém článku Ústavy, dle něhož mají občané kteréhokoli ze států nárok na stejné „,svobody a výsady“ jako občané ostatních států Unie. V roce 1823 bylo okrskovým soudem v Pensylvánii rozhodnuto v kauze Corfield v. Coryell, v jejímž odůvodnění se soudce Bushrod Washington kromě otázky regulace mezistátního obchodu zabývá podstatně rovněž otázkou svobod a výsad čtvrtého článku, když předkládá jejich demonstrativní výčet, do něhož pod obecnými formulacemi řadí mimo jiné právo projiždět či pobývat ve všech státech federace, právo na státní ochranu či nabývání a využívání vlastnických práv. ${ }^{41} \mathrm{~K}$ výčtu „,svobod a výsad“ $\mathrm{z}$ př́ipadu Corfield se v souvislosti se čtrnáctým dodatkem v odlišném stanovisku v kauze Sáenz v. Roe z roku 1999 na Nejvyšším soudu vrací i soudce Clarence Thomas, který v klauzuli o „svobodách a výsadách“ čtvrtého článku spatřuje inspiraci pro klauzuli „svobod nebo výsad“ čtrnáctého dodatku, jejíž znění má dle něho být vykládáno jako prosazení ochrany svobod a výsad, jak jsou uvedeny v kauze Corfield, vůči jednotlivým státům. ${ }^{42}$ Odpovědět zcela s jistotou na to, jaký je smysl „svobod nebo výsad“ v pojetí čtrnáctého dodatku, je ale bohužel prakticky nemožné. Význam klauzule zůstává nejednoznačný a ani Nejvyšší soud nevnesl od doby přijetí čtrnáctého dodatku do této nejistoty světlo. Pokud bychom zkoumali klauzuli o svobodách nebo výsadách z pohledu intencionalistické metody, rozhodujícím by pro nás musel být záměr navrhovatele dodatku. Ten známým je - kongresman John Bingham, tvůrce klauzule o svobodách nebo výsadách a „otec čtrnáctého dodatku“, ve svých vystoupeních před Kongresem dal několikrát svůj záměr najevo: klauzule o svobodách nebo výsadách měla sloužit jako nástroj pro prosazení Bill of Rights vůči státům. ${ }^{43}$ Úmysl tvưrce převládá nade vše a tvůrce se vyslovil nade vší pochybnost jasně. Avšak s tímto pohledem by se vykladači,

39 Slaughter-House Cases, 83 U.S. 36 (1873).

40 Barron v. Baltimore, 32 U.S. 243 (1833).

41 Corfield v. Coryell, 6 F. Cas. 546 (1823).

42 Sáenz v. Roe, 526 U.S. 489 (1999).

43 LASH, K. T. The Privileges or Immunities Clause and Unenumerated Rights. Law \& Liberty [online]. 21. 3. 2019 [cit. 2020-09-11]. Dostupné na: https://www.lawliberty.org/2019/03/21/the-privileges-or -immunities-clause-and-unenumerated-rights/. 
vyznávající odlišný interpretační př́stup, jen stěží ztotožnili. Originalistická metoda by dozajista neskončila svůj výzkum u úmyslu kongresmana Binghama. Jeho záměr je jednou věcí, druhou je však to, jak jím navrženou úpravu chápali ti, kdo rozhodovali o její ratifikaci - jejich srozumění zůstává pouze ve sfére dohadů. ${ }^{44} \mathrm{~A}$ pokud smyslem klauzule o svobodách a výsadách bylo aplikovat Bill of Rights vůči jednotlivým státům, tedy i včetně těch práv explicitně nezmíněných v Ústavě, znamenalo by to, že Nejvyšši soud by tímto byl autorizován ke zrušení těch státních legislativních aktů, které by s těmito právy byly $\mathrm{v}$ rozporu (a stal se slovy soudce Millera „,věčným cenzorem nad legislativou státì “45), ale zároveň by mu byl poskytnut prostor také $\mathrm{k}$ tomu, aby tato práva př́ípadně sám definoval, což je závěr, jaký originalismus již ze své podstaty odmítá, a od čehož se výslovně zdržel i sám Nejvyšší soud v rozsudku v jatečních př́padech. Naproti tomu teorie živé Ústavy s takovýmto přístupem v rozporu není, ba naopak - lze ho v podstatě označit za její esenci. Teoretici Ústavy coby žijícího dokumentu akcentují význam principů a hodnot, které nemusejí být přímo v ústavním textu jmenovány, ale soudci je mohou (a mají) chránit. V jatečních př́ípadech je takovou hodnotou právo svobodného obchodu a podnikání, dotčené vytvořením centrálního monopolu. Pokud s takovým právem sympatizujeme a považujeme ho za hodnotné, rozhodnutí Nejvyššího soudu v kauze ,jatka“ nám nebude „hodnotově“ sympatické. Přesto ho nicméně lze považovat za správné, pokud ovšem dospějeme k závěru, že bylo v souladu s ústavními ustanoveními. Teoretici, kritizující originalistický př́stup, upozorňují právě na to, že limitovaná role, jakou soudcům originalisté přisuzují, může vést $\mathrm{k}$ interpretaci, jejímž resultátem bude, že jisté nepsané hodnoty, které má dle nich chránit devátý dodatek Ústavy, ${ }^{46}$ nebudou respektovány (což vzhledem $\mathrm{k}$ jejich povaze považují za krajně nežádoucí), jako se tomu stalo v kauze jatečních případů. Odpovědí na tuto námitku může být stanovisko soudce Pottera Stewarta v jeho disentu v př́ipadu Griswold v. Connecticut (1965), v němž označil zákon, jehož ústavnost byla zkoumána, za „,nebývale hloupý“ ${ }^{47}$ ale přesto byl nucen ho prohlásit za ústavně konformní, čímž velmi dobře vystihl charakter originalismu - nemusí souhlasit s každým zkoumaným zákonem a je si vědom, že jeho zachování může být omezením pro svobodu, ale pokud dospějí $\mathrm{k}$ závěru, že Ústava takové omezení připouští, nelze jinak, než zákon zachovat a nechat na zákonodárcích, aby ho dle vůle lidu př́padně zrušili. Stewartovu formulaci o „nebývale hloupém“, nicméně Ústavě neodporujícím, zákonu poté o několik desítek let později zopakoval i Clarence Thomas ve stručném disentu v př́padu Lawrence, v němž byl prohlášen za neslučitelný se čtrnáctým dodatkem a tedy protiústavní texaský zákon o sodomii, kriminalizující homosexuální styk. ${ }^{48}$

Soudní praxe se každopádně v letech po rozhodnutí v jatečních případech držela precedentu v nich ustanoveném a aplikace Bill of Rights proti státům tak zůstávala zapovězena. Postupem času však došlo k prolomení této praktiky a dodatky, tvořící Bill of Rights, počaly být inkorporovány prostřednictvím čtrnáctého dodatku i vůči jednotli-

\footnotetext{
BORK, c. d., s. 181.

Slaughter-House Cases, 83 U.S. 36 (1873).

SELTENREICH - KUKLÍK, c. d., s. 561.

47 Griswold v. Connecticut, 381 U.S. 479 (1965).

48 Lawrence v. Texas, 539 U.S. 558 (2003).
} 
vým státům federace. Tato proměna byla vedena změnou v soudní interpretaci čtrnáctého dodatku, avšak tentokrát nikoli na základě klauzule o svobodách nebo výsadách, jejíž restriktivní pojetí, zformované v jatečních prrípadech, prozatím stále přetrvává, nýbrž na bázi jiné části čtrnáctého dodatku - klauzule o řádném procesu.

\subsubsection{DUE PROCESS}

Pátý dodatek Ústavy Spojených států garantuje právo na ,ř́ádný soudní proces“ (due process). Díky této ústavní garanci není možné zbavit kohokoli života, svobody či majetku bez ,řádného soudního procesu“. Jde tedy o procesní ochranu práv, která nesmí být odňata, aniž by byly dodrženy všechny náležitosti soudního procesu, zformulované detailněji v průběhu času díky činnosti soudů. Požadavek řádného procesu, vyjádřený v pátém dodatku, byl však až do přijetí čtrnáctého dodatku aplikovatelný pouze na federální úrovni. Přijetím čtrnáctého dodatku tak došlo k důležité změně v aplikaci jedné z nejdůležitějších doktrín zaručujících vládu práva, nebot' klauzule o řádném soudním procesu, obsažená v prvním oddílu, v něm byla nejen znovupotvrzena, ale zároveň byla textem nově vztažena i na jednotlivé státy federace. Klauzule řádného soudního procesu v podání čtrnáctého dodatku s sebou vedle působnosti vůči jednotlivým státům však přinesla ještě jednu neméně důležitou novotu - tou byl nový výklad samotné podstaty doktríny řádného soudního procesu. Zatímco dřívější pojetí řádného procesu bylo pojetím čistě procedurálním, nová interpretace, vyvinuvší se v průběhu času po rozhodnutí v jatečních př́ípadech, počala chápat ,ř́ádný soudní proces“ nikoli jako pouhý procedurální požadavek, nýbrž jako, ,rádný proces substantivní“ (substantive due process). ${ }^{49}$ Ochrana, jakou povinnost řádného soudního procesu poskytovala, tak získala zcela nový rozměr v podobě něčeho, co můžeme označit jako „hmotné jádro“ ‘̌ádného soudního procesu, tvořené samotnými právy, která mají být chráněna před státními zásahy v důsledku rozhodování společenské většiny. Doktrína substantive due process tedy na rozdíl od původní due process pátého dodatku, stanovujícího nutné prostř̌edky, jakými je možné zbavit člověka života, svobody či majetku, ztělesňuje samotná práva, která nemohou být předmětem státních zásahů.

Vzestup doktríny substantivního řádného procesu v americkém ústavním právu započal v raných letech dvacátého století, kdy Nejvyšší soud řešil řadu př́ípadů, týkajících se ekonomické svobody a př́pustnosti státní intervence do ekonomiky, z nichž nejpodstatnějším byl rozsudek v kauze Lochner v. New York (1905), v němž Nejvyšší soud zrušil newyorský zákon, regulující délku pracovní doby jakožto odporující smluvní svobodě, a tedy právu na svobodu v rámci čtrnáctého dodatku. Př́ípad Lochner se stal precedentem pro futuro, díky jehož výsledku získala doktrína substantivního řádného procesu své pevné místo v ústavním právu a od druhé poloviny dvacátého století se stala základem pro přelomové rozsudky v oblasti občanských práv. ${ }^{50}$ Poněkud paradoxně proto působí fakt, že k vůbec prvnímu uplatnění doktríny substantive due process došlo v již zmíněném nechvalně proslulém rozsudku v kauze Dred Scott v. Sandford, v němž Nejvyšší

49 SELTENREICH - KUKLÍK, c. d., s. 406.

50 PULLIAM, M. Leaving Lochner Behind. Law \& Liberty [online]. 7. 8.2017 [cit. 2020-09-11]. Dostupné na: https://lawliberty.org/leaving-lochner-behind/. 
soud pod vedením předsedy Rogera Taneyho označil vlastnictví otroků za ústavní právo právě na základě substantivního pojetí doktríny řádného procesu, a to 11 let předtím, než čtrnáctý dodatek vůbec vznikl. ${ }^{51}$ Taneyho zdůvodnění rozsudku je dodnes terčem kritiky zástupců prakticky všech výkladových směrů - Robert Bork odsuzuje Taneyho argumentaci z originalistické perspektivy i s poukazem na negativní efekt, jaký měla do budoucna, kdy soudci dle Borka na základě substantivního řádného procesu vpisovali do Ústavy „svá osobni přesvědčení, která Ústava však neobsahuje “.52 Příklady takových rozhodnutí, jež dle Borka i jiných originalistů ztělesňují ukázku „soudcovského aktivismu“, jsou Griswold v. Connecticut (1965) a Roe v. Wade (1973). V kauze Griswold Nejvyšší soud nalezl v Ústavě „spojením“ prvého, třetího, devátého a také čtrnáctého dodatku nové ústavní právo na soukromí, jež je dle většinového stanoviska jednou z nepsaných záruk, majících v Ústavě své „,polostíny“, pomáhající jim vdechnout „život a podstatu“ “. ${ }^{53} \mathrm{Na}$ toto rozhodnutí poté navázal $\mathrm{v}$ jednom z nejproslulejších sporů americké právní historie, když v př́padu Roe v. Wade zahrnul pod právo na soukromí, vzniklé v rozhodnutí $\mathrm{v}$ kauze Griswold, právo ženy ukončit těhotenství kdykoli během prvního trimestru. ${ }^{54}$ Podobně jako Bork i profesor John Hart Ely, jedna z nejvlivnějších osobností americké právní teorie dvacátého století a také Borkův kritik, označuje pojem „substantivní ŕádný process“ jako „protimluv“, 55 nebot” dle Elye se zkrátka „,nelze vyhnout faktu, že slovo ,rádný je následováno slovem ,proces' a neexistuje žádnýd dỉkaz, že slovo ,proces' znamenalo [v době ratifikace dodatku] něco jiného, než znamená nyni' “.56 Poněkud ambivalentní postoj $\mathrm{k}$ doktríně substantivního řádného procesu zaujal Oliver Wendell Holmes jr., mimo jiné také autor disentu v př́ípadu Lochner. Holmes na jedné straně odmítl, aby jakákoli ekonomická filozofie měla vliv na interpretaci Ústavy a soudci aby na jejím základě bránili přirozenému rozhodování většiny, na straně druhé však neodmítl koncepci substantivního řádného procesu jako takovou, když přiznal existenci určitých fundamentálních principů, které nepotřebují výslovné zmínění v Ústavě k jejich aplikovatelnosti, vycházejíc z tradic amerického lidu a práva. ${ }^{57}$ Pojem substantivního řádného procesu s sebou dozajista přináší svá pozitiva - pokud přiznáme, že existují jisté základní principy, $v$ Ústavě explicitně nevepsané, avšak svou povahou natolik zásadní pro svobodnou demokratickou společnost, že je potřeba soudce nadat pravomocí je chránit i bez opory psaného textu, riziko potenciální tyranie a utlačování menšin je velmi podstatně sníženo. Nese s sebou však také rizika s ním spojená - jak totiž zabránit soudcům, aby při výkladu Ústavy nevymezili ony základní fundamentální principy svévolně a neopírali je pouze o své subjektivní přesvědčení, čímž by mohli paradoxně ke zničení demokracie přispět oni sami? Jak lze již tušit, podobná varování přichází ze strany zastánců textualistického a originalistického výkladu. Můžeme proto souhlasit s názorem profesora Thomase Greye, jenž označuje koncept substantivního řádného

51 BORK, c. d., s. 31.

52 Tamtéž.

53 Griswold v. Connecticut, 381 U.S. 479 (1965).

54 Roe v. Wade, 410 U.S. 113 (1973).

55 ELY, J. H. Democracy and Distrust: a Theory of Judicial Review. Cambridge: Harvard University Press, 2002, s. 18.

56 Tamtéž.

57 Lochner v. New York, 198 U.S. 45 (1905). 
procesu za přímo neslučitelný s tím, co nazývá „,model ryze výkladový“ “58 jehož popis odpovídá zmíněným dvěma metodám výkladu.

Jak pojem ,řádného soudního procesu“ ve čtrnáctém dodatku vnímaly osoby, které ho ratifikovaly, je obtížné odhalit. Některé části debat, provázejících schvalování čtrnáctého dodatku, se nedochovaly a zůstávají nám tak zapovězeny. Podle profesora Elye vzhledem $\mathrm{k}$ rozsudkům, týkajícím se doktríny due process, vyneseným ještě před vznikem čtrnáctého dodatku, jenž byly tvůrcům dodatku i ratifikujícím dozajista známé, není možné stoprocentně vyloučit, že by si nepřáli, aby klauzule o řádném procesu byla př́ležitostně vykládána substantivně, ${ }^{59}$ zároveň je zde ale také názor profesora Stanfordovy univerzity Samuela Morrisona, jehož Ely rovněž cituje, podle něhož výklad klauzule o řádném soudním procesu v souladu s jeho původním významem znamená, že substantivní pojetí klauzule nemůže být ospravedlnitelné. ${ }^{60}$

Pokud uvážíme zcela nepochybnou inspiraci tvůrců čtrnáctého dodatku pátým dodatkem při konstrukci klauzule o řádném procesu, stejně jako jejich snahu o vztažení pátého dodatku na jednotlivé státy prostřednictvím nového dodatku čtrnáctého, a rovněž absenci explicitního zmínění adjektiva „substantivní “v samotném textu dodatku či dostupných historických materiálech, lze dovozovat - jak konstatuje soudce Nejvyššího soudu Byron White - že substantivní pojetí řádného procesu nemá ústavní oporu. ${ }^{61}$ Díky Nejvyššímu soudu a jeho historické činnosti v průběhu celého dvacátého století však dnes toto pojetí stále zůstává platným i uplatňovaným.

\subsubsection{EQUAL PROTECTION OF THE LAWS}

Na rozdíl od klauzulí o svobodách nebo výsadách a rádném soudním procesu, u klauzule o stejné ochraně zákona (equal protection of the laws) nenacházíme obdobnou formulaci v jiných částech Ústavy. V době jejího navržení šlo o naprosto novou právní úpravu, zformulovanou jako prostředek pro prosazení potřebných změn v oblasti rasové rovnosti. Navzdory všeobecně známému cíli, kterému měla klauzule o stejné ochraně zákona sloužit, - povýšit obsah Zákona o občanských právech z roku 1866 na ústavní úroveň ${ }^{62}$ - Nejvyšší soud zasadil této snaze tvrdý zásah rozsudkem v př́ípadu Plessy v. Ferguson (1896). V něm neshledal protiústavním louisianský zákon, zakotvující segregaci ve vlakové dopravě v podobě oddělených vagonů pro osoby černé a bílé pleti, když argumentoval, že odlišné zacházení neimplikuje zároveň rasovou inferioritu, nebot' stejně jako osoby černé pleti nemohly cestovat pohromadě s osobami pleti bílé, stejné pravidlo platilo i vice versa. ${ }^{63}$ Toto rozhodnutí tudíž učinilo původnímu významu klauzule o stejné ochraně ráznou přítrž a namísto odbourání rasové diskriminace uvolnilo cestu nové doktríně separate but equal („odděleni, ale rovni“). Nic na tom nezměnilo ani známé osamocené odlišné stanovisko soudce Harlana, hovořícího o „barvoslepé Ústavě“ (color-blind Constitution), která nepřipouští arbitrární oddělo-

\footnotetext{
8 SELTENREICH - KUKLÍK, c. d., s. 562.

9 ELY, c. d., s. 16.

60 Tamtéž, s. 15.

61 Moore v. City of East Cleveland, 431 U.S. 494 (1977).

62 MCGINNIS - RAPPAPORT, c. d., s. 110.

63 Plessy v. Ferguson, 163 U.S. 537 (1896).
} 
vání občanů podle rasy, které se v podstatě rovná jejich poznamenávání „odznakem otroctvi““. Př́ípad Plessy se tak stal pomyslnou licencí jižanským státům pro přijímání diskriminačních opatření, jakými byly oddělené prostory v dopravních prostředcích či restauračních zařízeních. Precedent, stanovený v kauze Plessy, vládl po dlouhá léta až do roku 1954. Až tehdy byla prolomena doktrína separate but equal, a to znovu díky Nejvyššímu soudu, vstupujícímu pod vedením předsedy Earla Warrena do nové „liberálni' éry, jejímž symbolem se stal rozsudek v kauze Brown v. Board of Education of Topeka, v níž byla ústavnímu přezkumu podrobena legislativa, umožňující segregaci ve veřejných školách na základě rasy. Warrenův soud jednomyslným rozhodnutím segregaci ve veřejných školách prohlásil za protiústavní. Bohužel, odůvodnění, jaké soud přednesl, stálo spíše na sociologické než právní bázi a rozhodnutí tak neobsahuje detailní právní analýzu př́slušných ustanovení čtrnáctého dodatku, s odvoláním na nějž Warrenův soud kauzu rozsoudil. ${ }^{64}$

Pojem stejné ochrany zákona demonstruje zřejmě nejlépe ze všech klauzulí čtrnáctého dodatku rozdíl mezi teoriemi, zaměřenými na přesné znění textu a jeho původní význam, a metodou pragmatického čtení textu, beroucí v potaz společenský vývoj a měnící se okolnosti, za nichž je text aplikován. Originalistická teorie původního významu nahliží na klauzuli o stejné ochraně zákona jako na nástroj, jímž mělo být dosaženo zrovnoprávnění čerošské populace s většinovou bílou populací, tedy jako na prostředek, jenž má svůj úzce vymezený účel, za nímž byl přijat, a který nelze vztahovat na př́ípady nesouvisející s otázkami rasové rovnosti. Profesor Grey ve svém eseji Máme nepsanou Ústavu? vyčítá originalistické a textualistické metodě, že dává prostor federální vládě pro „explicitní rasovou diskriminaci“65 (klauzule stejné ochrany zákona je aplikovatelná na státní, nikoli federální úrovni). Zásadní rozpor mezi textualisty/originalisty a teoretiky „živé Ústavy“ nastává v rozsahu, v jakém je možné klauzuli o stejné ochraně zákona aplikovat. $\mathrm{V}$ průběhu druhé poloviny dvacátého století začal Warrenův soud, následovaný dalšími, interpretovat pojem stejné ochrany zákona na všechny případy, související s nestejným postavením, nikoli pouze na ty, týkající se nestejného postavení z důvodu barvy pleti. Nejvýznamnějším z prŕípadů v posledních letech, na něž byla užita klauzule o stejné ochraně zákona v rozšířeném pojetí, je kauza Obergefell v. Hodges (2015), v níž Nejvyšší soud na základě extenzivní interpretace klauzulí čtrnáctého dodatku o řádném procesu a stejné ochraně zákona shledal, že Ústava garantuje v rámci svobody chráněné klauzulí o řádném procesu právo na stejnopohlavní sňatky, uplatnitelné vůči všem státům. ${ }^{66}$ Podobný závěr je naprosto logickým vyústěním interpretace Ústavy coby žijícího a vyvíjejícího se dokumentu, jistě však nebude konvenovat stoupencům teorie původního významu. Proto je nutné se ptát, jaký princip ochrany klauzule o stejné ochraně zákona skutečně zakotvuje. Jde o princip rovnosti osob černé pleti s osobami pleti bílé? Nebo jde o obecný princip rovnosti všech ras? Či snad jde o princip rovnosti přesahující oblast rasy úplně? Řešením, jak nalézt požadovaný princip, jenž bude natolik obecný, že ho bude možné aplikovat na více príipadů, může být volba této úrovně abstraktnosti soudcem, aplikujícím vykládaný text na daný př́pad. Druhou možností je poté ř́́dit

64 Brown v. Board of Education of Topeka, 347 U.S. 483 (1954).

65 SELTENREICH - KUKLÍK, c. d., s. 562.

66 Obergefell v. Hodges, 576 U.S. 644 (2015). 
se pouze textem, tj. nalézt jeho skutečný význam, aniž bychom volbu míry obecnosti ponechali na vykladači textu. Které řešení zvolíme a považujeme za správné, záleží už jen na našem chápání práva, Ústavy a úlohy jejích vykladačů.

\section{ZÁVĚR}

Budoucnost interpretace čtrnáctého dodatku je dnes nemožné s absolutní přesností př́edvídat. Lze se však důvodně domnívat, že bude prrímo záviset na složení Nejvyššího soudu a predominující právní filozofii většiny jeho členů, kteří budou v oblasti vývoje výkladu díky své pravomoci soudního přezkumu hlavními aktéry. Současné složení Nejvyššího soudu má po dvou úspěšných nominacích prezidenta Donalda Trumpa - Neilu Gorsuchovi a Brettu Kavanaughovi - blíže ke konzervativnímu myšlenkovému proudu, který se již dlouhou dobu zasazuje o zvrácení některých problematických rozsudků, zejména $\mathrm{v}$ kauze Roe $\mathrm{v}$. Wade, jejíž opětovný přezkum ve světle nových legislativ, prijímaných napříč Spojenými státy, se jeví jako pravděpodobný. Osud této kauzy, stejně jako i dalších pojících se se čtrnáctým dodatkem, ale zdaleka není jistý, již proto, že navzdory republikánské převaze v Nejvyšším soudu nepřevažuje také vyhraněné originalistické či textualistické smýšlení, zastávané především soudci Clarencem Thomasem a Samuelem Alitem, a jak nově jmenovaný Brett Kavanaugh, tak předseda John G. Roberts se řadí spíše k centristickému proudu, reprezentovanému svého času kupř́kladu soudcem Anthonym Kennedym. Nezbývá tedy než konstatovat, že osud výkladu čtrnáctého dodatku zůstane alespoň prozatím v rukou oněch pomyslných devíti strážců ústavnosti a jejich uvážení, jež odhalí až čas.

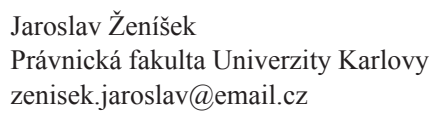

